\title{
Melanophila unicolor Gory, 1841 (Buprestidae), the furnace beetle, in southern Africa
}

\author{
C.H. Scholtz ${ }^{1 *} \&$ T.C. MacRae ${ }^{2}$ \\ ${ }^{1}$ Department of Zoology and Entomology, University of Pretoria, Pretoria, 0002 South Africa \\ ${ }^{2}$ Monsanto Company, 700 Chesterfield Parkway West, Chesterfield, Missouri 63017, U.S.A.
}

Recently, large numbers of Melanophila unicolor Gory, 1841 were attracted to furnaces and cooling copper at a smelter at Tsumeb, Namibia, where the beetles are colloquially known as 'furnace-beetles'. The smelter is surrounded by indigenous savanna woodland. The beetles were alleged by workers to inflict a painful bite. Specimens were sent to us for identification; the results are reported in this communication.

There has been considerable confusion over the years about which species of Melanophila occur in southern Africa and little documentation that the adult beetles demonstrate the same heat-seeking behaviour reported for the northern hemisphere species. There is one published account of these beetles in South Africa being attracted to a steel foundry (Holm \& Bellamy 1985), and a few museum specimens record them collected at camp fires and near industrial furnaces of some kind. However, all South African members of the genus possess the same infrared receptors that are a major taxonomic character differentiating them from related genera, thus they can be presumed to be thermophilous.

Melanophila primarily is a Holarctic genus consisting of 12 species with, until the present study, possibly more than one species known from southern Africa. All Holarctic species are associated with freshly-burnt conifers which provide food for the wood-boring larvae (Evans 1964), although one North American species, M. occidentalis Obenberger, 1928, regularly breeds in a variety of broadleaf trees and shrubs (Barr \& Linsley 1943). The southern African records are from savanna areas where conifers are absent, suggesting Melanophila in South Africa regularly utilises non-conifer hosts.

From specimens examined in two South African museums (National Collection of Insects, Agricultural Research Institute, Pretoria, and Ditsong National Museum of Natural History, Pretoria) and those collected recently at Tsumeb in Namibia that we identified using keys and descriptions in

*Author for correspondence. E-mail: chscholtz@zoology.up.ac.za
Cobos' (1987) revision of the genus, we concluded that only one species, M. unicolor Gory, occurs in southern Africa (Botswana, Namibia, South Africa and Zimbabwe - this study, and Angola and Mozambique - Bellamy 2008). However, there are various names applied to the small number of specimens in the above museums which are either synonyms of extralimital species or refer to species known from other regions.

Names that have been attributed to southern African specimens are M. nigrita (Fabricius, 1798), M. lugubrina (Fåhraeus, 1851) and M. cuspidata (Klug, 1829). Melanophila nigrita is considered a synonym of the widespread Palearctic species M. cuspidata and M. lugubrina is considered synonymous with M. unicolor (Cobos, 1987). Thus in our interpretation of the genus, there are two Palearctic species also found either in West Africa (M. cuspidata) or North Africa (M. gestroi Obenberger, 1923), but only one southern African species, M. unicolor (Fig. 1).

Adults of both sexes are strongly attracted to burning trees, where mating takes place and where females lay eggs under the bark of smouldering wood. They appear to be able to tolerate far higher temperatures than most other insects and have been seen to perch adjacent to glowing timber and sit on metals hot to the human touch (Evans 1964, 1966a, b, 2005). The actual temperature that they experience or for how long they can tolerate these high temperatures have not been measured; however, there is one anecdotal report of $M$. unicolor (as M. nigrita) being able to tolerate temperatures of up to $60^{\circ} \mathrm{C}$ (Holm \& Bellamy 1985). It is surmised that the females approach as close as possible to the burnt or burning wood because the heat destroys plant secondary metabolic products in the wood that may supress or restrict development of the wood-boring larvae. The species probably also gain a competitive advantage by being the first to find and exploit newly available resource ahead of other species of wood-boring beetles (Evans 1971). Larvae only develop in wood of trees freshly-killed by fire 


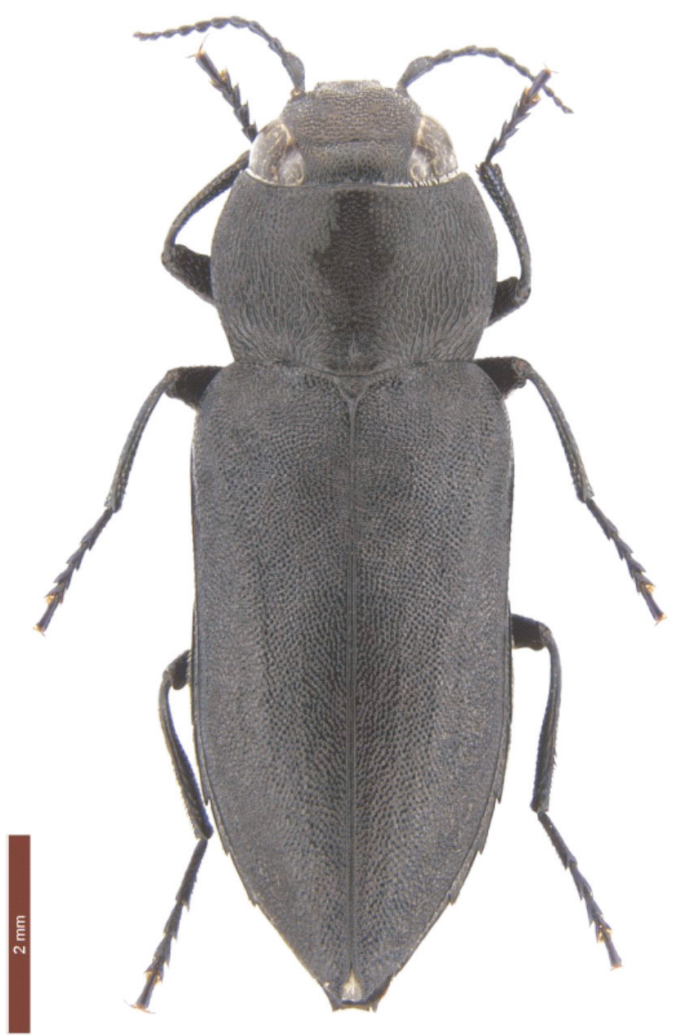

Fig. 1. Dorsal view of Melanophila unicolor (Gory). Pronotal sculpture and the shape of the elytral apices include diagnostic characters of the species.

(Evans 1964), although adults of the Holarctic M. acuminata (DeGeer, 1774) have been observed ovipositing on conifers cut for lumber (Evans 1962). In southern Africa and North America, adults have been reported to bite when they land on a person. Workers at the copper smelter in Namibia claimed the bite is painful, and Linsely \& Hurd (1957) state that the beetles are 'heartily disliked' by workmen at cement plants in southern California. This may be related to their apparent insect-eating habits - adults have been observed feeding on scorched insects in the field (Ricksecker 1885) and readily consume insect prey in captivity (Evans 1962), a highly unusual but understudied deviation from the diet of their pollen- and foliage-feeding relatives.

Melanophila beetles detect smoke and infrared radiation from burning trees using two independent systems; antennal smoke detectors (Schütz et al. 1999) and thoracic infrared sensors (Evans 1964, 1966a, b, 2005). It has not been established, though, how information acquired by the systems is neurally integrated.

Infrared wavelengths are longer (about $750 \mathrm{~nm}$ $-1 \mathrm{~mm}$ ) than those of visible light and are produced by warm objects radiating heat. Some insects are capable of sensing infrared wavelengths from radiant heat with special sensors that process them into a sensory signal in the brain. Heat sources of importance to insects in nature are produced by warm-blooded animals such as birds and mammals, and some of their parasites use the infrared rays they produce as orientation cues. Mosquitoes also use it as one of a suite of cues to locate their hosts (Jones 2013). However, the most remarkable example of infrared detection has been recorded in members of the jewel beetle genus, Melanophila (Evans 1964, 1966a, b, 2005; Vondran et al. 1995; Schmitz et al. 2007).

The use of antennal smoke-detectors is unknown in any other insect species, and the paired, mesothoracic, infrared detecting pit organs are more complex than any other similar biological system yet discovered. They are well-known in blood-feeding insects such as bedbugs, in socalled pitviper rattlesnakes, some boas and pythons, as well as in vampire bats (Evans 2005). In the U.S.A., Melanophila beetles have been recorded to fly across a barren, desert landscape to an oil-fire over distances of some $80 \mathrm{~km}$ from the nearest conifer forests. Smoke detection and infrared attraction by the Holarctic species, M. acuminata, have been thoroughly investigated, and from general reports and anecdotal information it appears as if all species in the genus have the infrared detectors on the thorax (Sloop 1937) and use them to aid in detecting fires (Evans 1964, 1966a, b, 2005).

In the U.S.A. and Europe Melanophila species have been attracted to forest and oil fires as well as industrial heat-producing processes such as smelter plants and burning rubbish in refuse dumps. An early record from Britain quotes '...scorched by the burning peat and half choked by the blinding smoke, we added quite a novel episode to our experiences in collecting beetles, for on the ground on which it was too hot to place one's hand, many Melanophila were running. They were settled...on pine stumps actually glowing...or flying through drifts of acrid peat smoke' (Sharp 1918). An equally delightful anecdote from California in the 1940s quotes beetles being attracted to a football stadium during matches 


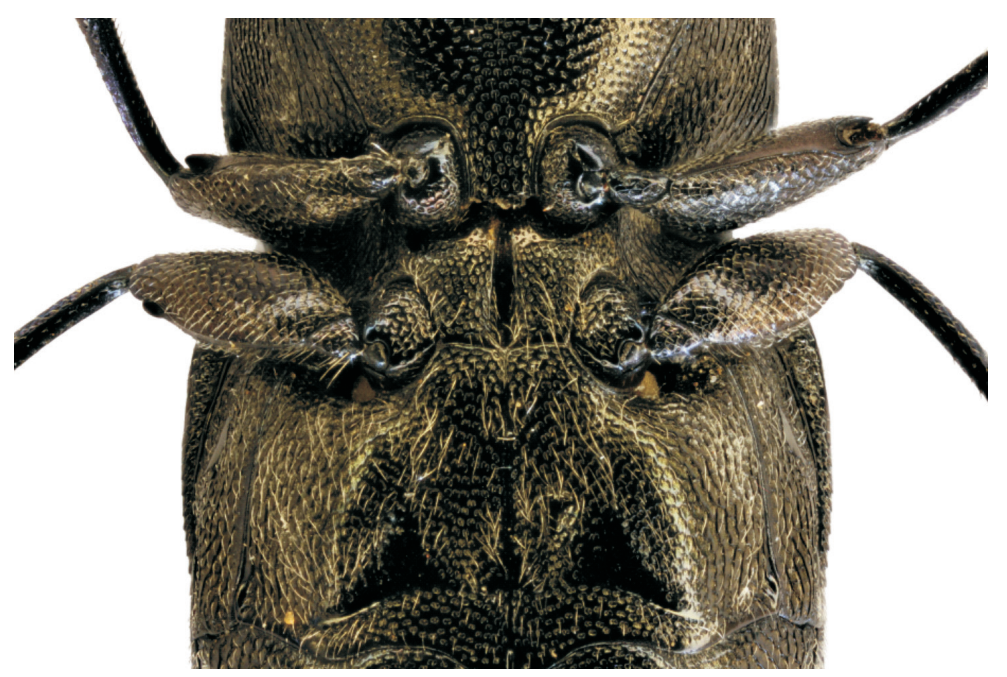

Fig. 2. Ventral view of Melanophila unicolor (Gory) illustrating infrared sensory pits adjacent to mesocoxae.

'... where they occasionally swarm in sufficient numbers to annoy patrons by ... or even biting the neck or hands. It is possible that in this case the beetles are attracted by the smoke from some 20000 cigarettes, which on still days sometimes hangs like a haze over the stadium...' (Linsley 1943).

The paired infrared sensory pit organs lie adjacent to the coxae of the middle legs (Fig. 2). They are $450 \mu \mathrm{m} \times 200 \mu \mathrm{m}$ in diameter and consist of about 70 domed sensilla at the bottom of the pit (Fig. 3). Each sensillum is a domed-shaped structure covered by very thin cuticle $(1 \mu \mathrm{m})$, and each is accompanied by a multiporous wax gland that continuously produces wax filaments which completely fill the pit with a three-dimensional network of coalesced wax fibres. These are thought to protect the sense organs from dust particles and to help reduce water loss through the thin cuticle in the area (Vondran et al. 1995; Schmitz et al. 2007).

The sensilla are derived from common mechanoreceptors (sensilla trichodea) (Vondran et al. 1995; Schmitz et al. 2007). Maximum sensitivity is for wavelengths of about $3 \mu \mathrm{m}$ (range of $2.5 \mu \mathrm{m}$ to $4.0 \mu \mathrm{m})$ and an energy level of $6.0-10^{-5}$ $\mathrm{W} / \mathrm{cm}^{2}$. This sensitivity range is equivalent to

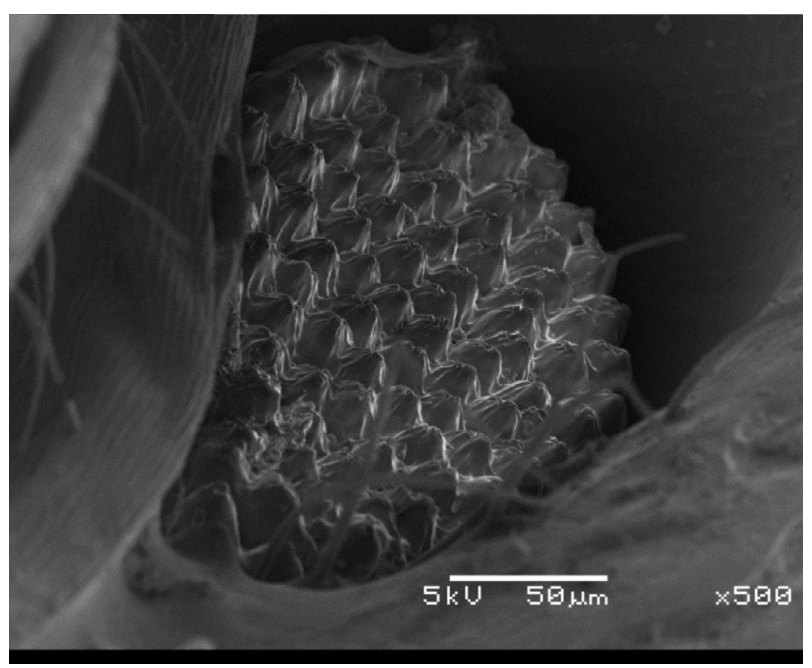

Fig. 3. Scanning electron micrograph (×500 magnification) of an infrared sensory pit on Melanophila unicolor (Gory), illustrating surface structure. 
the radiation energy of a forest fire generating temperatures of between $425^{\circ} \mathrm{C}$ and $1150{ }^{\circ} \mathrm{C}$ and perceived over a distance of many kilometres. The sensory pits are exposed during flight which probably allows the beetles to steer tropotactically (using each of the pits to independently and alternately assess the signal) and orientating towards the infrared source.

The antennal smoke detectors are responsive to various volatile chemicals that are emitted by burning wood (pyrolysis), of which guaiacol elicits the greatest response (Schütz et al. 1999). Guaiacol results from pyrolysis of lignin and, when bound to oxygen, turns yellowish-brown; it is the substance that imparts the typical colour of, and smoky taste, to smoked food. However, burning wood produces a suite of different volatiles, many

\section{REFERENCES}

BARR, W.F. \& LINSLEY, E.G. 1947. Distributional and biological notes on the species of the subgenus Melanophila occurring in western North America (Coleoptera: Buprestidae). The Pan-Pacific Entomologist 23(4): 162-166.

BELLAMY, C.L. 2008. A World Catalogue and Bibliography of the Jewel Beetles (Coleoptera: Buprestoidea), Volume 3: Buprestinae: Pterobothrini through Agrilinae: Rhaeboscelina. Pensoft Series Faunistica No. 78: 1260-1931, Pensoft Publishers, Sofia, Bulgaria, and Moscow, Russia.

COBOS, A. 1987. Ensayo mongráfico sobre las Melanophila Eschscholtz sensu lato (Coleoptera: Buprestidae). 1 Parte: Melanophila Eschs., sensu novo; Trachypteris Kirby; Xenomelanophila Sloop. EOS, Revista Español de Entomologia 62: 45-90.

EVANS, W.G. 1962. Notes on the biology and dispersal of Melanophila (Coleoptera: Buprestidae). The Pan-Pacific Entomologist 38: 59-62.

EVANS, W.G. 1964. Infrared receptors in Melanophila acuminata DeGeer. Nature 202: 211.

EVANS, W.G. 1966a. Morphology of the infrared sense organs of Melanophila acuminata (Buprestidae: Coleoptera). Annals of the Entomological Society of America 59(5): 873-877.

EVANS, W. G. 1966b. Perception of infrared radiation from forest fires by Melanophila acuminata De Geer (Buprestidae: Coleoptera). Ecology, 47(6): 1061-1065.

EVANS, W.G. 1971. The attraction of insects to forest fires. 115-127. In: Proceedings of the 11th Tall Timbers Conference on Ecological Animal Control by Habitat Management, 25-27 February 1971, Tall Timbers Research Station, Tallahassee, Florida, U.S.A.

EVANS, W.G. 2005. Infrared radiation sensors of Melanophila acuminata (Coleoptera: Buprestidae): A thermopneumatic model. Annals of the Entomological Society of America 98(5): 738-746. of which are, no doubt, specific to the particular tree burning, and which the beetles may use to identify preferred larval host tree species.

\section{ACKNOWLEDGEMENTS}

We are indebted to A. van Tonder who provided us with specimens of Melanophila unicolor from Namibia as well as some background information on the beetles' furnace-frequenting habits at the Tsumeb smelter. The curators of Coleoptera at the National Collection of Insects (R. Stals) and of the Ditsong National Museum of Natural History (S. Mlambo) lent us specimens in their care for study. C. Jacobs, C. Deschodt and W. Strümpher from the Scarab Research Group at the University of Pretoria, provided technical assistance.

HOLM, E. \& BELLAMY, C.L. 1985. Buprestoidea. In: Scholtz, C.H. \& Holm, E. (Eds). The Insects of Southern Africa. Butterworths, Durban, South Africa.

JONES, W. 2013. Olfactory carbon dioxide detection by insects and other animals. Molecules and Cells 35(2): 87-92.

LINSLEY, E.G. 1943. Attraction of Melanophila beetles by fire and smoke. Journal of Economic Entomology 36(2): 341-342.

LINSLEY, E.G. \& HURD, P.D., Jr. 1957. Melanophila beetles at cement plants in southern California (Coleoptera, Buprestidae). The Coleopterists Bulletin 11(1): 9-12.

RICKSECKER, L.E. 1885. [Notes on woodboring beetles in California]. Entomologica Americana 1(5): 96-98.

SHARP, W.E. 1918. Melanophila acuminata DeG in Berkshire. Entomologist's Monthly Magazine 54: 244-245.

SCHÜTZ, S., WEISSBECKER, B., HUMMEL, H.E., APEL, K.H., SCHMITZ, H. \& BLECKMANN, H. 1999. Insect antenna as a smoke detector. Nature 398(6725): 298-299.

SCHMITZ, A., SEHRBROCK, A. \& SCHMITZ, H. 2007. The analysis of the mechanosensory origin of the infrared sensilla in Melanophila acuminata (Coleoptera: Buprestidae) adduces new insight into the transduction mechanism. Arthropod Structure \& Development 36(3): 291-303.

SLOOP, K.D. 1937. A revision of the North American buprestid beetles belonging to the genus Melanophila (Coleoptera, Buprestidae). University of California Publications in Entomology 7: 1-20.

VONDRAN, T., APEL, K.H. \& SCHMITZ, H. 1995. The infrared receptor of Melanophila acuminata De Geer (Coleoptera: Buprestidae): ultrastructural study of a unique insect thermoreceptor and its possible descent from a hair mechanoreceptor. Tissue and Cell 27(6): 645-658.

Accepted 27 August 2015 